\title{
Spontán bakteriális peritonitis
}

\author{
Velkey Bálint dr. ${ }^{1}$ - Vitális Eszter dr. ${ }^{2}$ - Vitális Zsuzsanna dr. ${ }^{1}$ \\ Debreceni Egyetem, Általános Orvostudományi Kar, \\ ${ }^{1}$ Belgyógyászati Intézet, Gasztroenterológia Nem Önálló Tanszék, \\ ${ }^{2}$ Aneszteziológiai és Intenzív Terápiás Tanszék, Debrecen
}

\begin{abstract}
A spontán bakteriális peritonitis megjelenésére ascitessel járó májzsugorban szenvedőknél számíthatunk. A kórokozók intestinalis bakteriális transzlokáció útján a véráramba jutnak, majd az ascitesbe kerülve elszaporodnak. A betegség diagnózisa az ascites megemelkedett neutrofilszámának igazolásán alapszik $(>0,25 \mathrm{G} / \mathrm{L})$. A tenyésztés gyakran álnegatív, az antibiotikum-érzékenység meghatározása miatt mégis fontos. Kezelésére stabil betegekben iv., majd orálisan alkalmazott ciprofloxacint vagy amoxicillin/klavulánsavat ajánlanak, súlyosabb állapotban III. generációs cefalosporint. Nosocomialis infekció esetén a gyakoribb Gram-pozitív és antibiotikum-rezisztens patogének okozta fertőzés miatt imipenemet vagy meropenemet célszerú választani. Profilaxisként norfloxacint javasolnak, bár a fokozódó rezisztenciával számolni kell. Gastrointestinalis vérzés esetén öt napon át alkalmazott norfloxacin, súlyos májelégtelenek vérzése esetén ceftriaxon adása indokolt. Tartós antibiotikum-profilaxist (napi 400 mg norfloxacin) - primer prevencióként - alacsony ascitesösszfehérje-szintü, előrehaladott májzsugorosok számára ajánlanak, míg szekunder prevenció gyanánt minden spontán bakteriális peritonitisből felépült beteg számára indokolt adni. Nem mindenki ért egyet a tartós antibiotikum-profilaxissal. A cikk megírásának ösztönzője volt az a mindennapi tapasztalat, hogy a kórképpel kapcsolatos ismeretek nem eléggé állnak a cirrhosis kezelésének középpontjában. Orv. Hetil., $2017,158(2), 50-57$.
\end{abstract}

Kulcsszavak: májzsugor, intestinalis bakteriális transzlokáció, kezelés, profilaxis

\section{Spontaneous bacterial peritonitis}

Spontaneous bacterial peritonitis occurs most commonly in cirrhotic patients with ascites. Pathogens get into the circulation by intestinal translocation and colonize in peritoneal fluid. Diagnosis of spontaneous bacterial peritonitis is based on elevated polymorphonuclear leukocyte count in the ascites $(>0,25 \mathrm{G} / \mathrm{L})$. Ascites culture is often negative but aids to get information about antibiotic sensitivity in positive cases. Treatment in stable patient can be intravenous then orally administrated ciprofloxacin or amoxicillin/clavulanic acid, while in severe cases intravenous III. generation cephalosporin. Nosocomial spontaneous bacterial peritonitis often caused by Gram-positive bacteria and multi-resistant pathogens can also be expected thus carbapenem should be the choice of the empiric treatment. Antibiotic prophylaxis should be considered. Norfloxacin is used most commonly, but changes are expected due to increase in quinolone resistance. As a primary prophylaxis, a short-term antibiotic treatment is recommended after gastrointestinal bleeding for 5 days, while long-term prophylaxis is for patients with low ascites protein, and advanced disease $(400 \mathrm{mg} /$ day). Secondary prophylaxis is recommended for all patients recovered from spontaneous bacterial peritonitis. Due to increasing antibiotic use of antibiotics prophylaxis is debated to some degree.

Keywords: spontaneous bacterial peritonitis, antibiotic prophylaxis, treatment

Velkey, B., Vitális, E., Vitális, Zs. [Spontaneous bacterial peritonitis]. Orv. Hetil., 2017, 158(2), 50-57.

(Beérkezett: 2016. október 10.; elfogadva: 2016. november 15.)

\section{Rövidítések}

C3 = komplement 3; CA-SBP $=($ community acquired SBP $)$ közösségben szerzett SBP; fvs. = fehérvérsejt; GNB = Gramnegatív baktérium; GPC = Gram-pozitív coccusok; LBP = lipopoliszacharid-kötő protein; NOD2 = (nucleotide-binding oligomerization domain-containing protein 2) nukleotidkötő oligomerizációs domént tartalmazó protein; N-SBP = nosocomialis SBP; $\mathrm{PMN}=$ polimorfonukleáris leukocyta; $\mathrm{PPI}=$ protonpumpa-inhibitor; $\mathrm{SBP}=$ spontán bakteriális peritonitis; SIBO $=($ small intestinal bacterial overgrowth $)$ vékonybél bakteriális túlnövekedés; TLR2 = Toll-like receptor 2 ; vvt. = vörösvértest 
A májcirrhosisban szenvedő betegek fogékonyak a különböző bakteriális infekciókkal szemben. A betegség a leggyakoribb szerzett immundeficiens állapot. A fertőzések megjelenésére gyakrabban számíthatunk, a lefolyásuk súlyosabb, a mortalitásuk magasabb a nem cirrhosisos populációhoz képest. Különös jelentőségét azonban nemcsak ez adja. Következményként a máj funkcionális kapacitása hirtelen romolhat, cirrhosissal összefüggő különböző szövődmények jelenhetnek meg, vagyis akut dekompenzáció kialakulásához vezethetnek. Rontják a betegség prognózisát. Így a rövid és a hosszú távú halálozást is növelik. A fogékonyság fokozódásának hátterében a cirrhosis súlyosbodásával párhuzamosan romló immunfunkciók állnak. Az ascitessel bíró cirrhosisos betegek leggyakoribb fertőzése a spontán bakteriális peritonitis (SBP). A baktériumok a vérárammal érkeznek a hasüregbe. A leggyakoribb belépési kapunak a kórosan áteresztő bélnyálkahártyát tartják.

\section{A cirrhosis dekompenzációja}

A szövettani átalakulás ellenére a májzsugor tartósan tünetmentes lehet. A folyamat előrehaladásával előtérbe kerülnek a portalis hypertensióra és parenchymás elégtelenségre utaló fizikális és laboreltérések (krónikus progresszió jeleként a májzsugor dekompenzálódik). Ez a krónikus romlás az etiológiától függő gyorsasággal megy előre, ritkán stagnálhat is, ha a kiváltó tényezőt időben sikerült eliminálni (például a hepatitis C-vírus eradikációja megtörtént). Bizonyos hatásokra - leggyakrabban bakteriális infekció, akut hepatitis, nagyobb mennyiségú alkoholfogyasztás, gastrointestinalis vérzés - akut dekompenzáció következhet be, amely súlyos esetben a beteg halálához vezethet, még akkor is, ha eredetileg jó állapotú, enyhe cirrhosisban szenvedő betegben jelentkezett az akut dekompenzáció. Ha ezt az epizódot túléli, javulás várható, a dekompenzációt megelőző állapothoz közeli stádiumba juthat. Többnyire azonban nem múlik el nyomtalanul egy ilyen esemény, a hosszú távú prognózis romlása várható (1. ábra). Akut dekompenzáció idején a Child-Pugh-stádium hirtelen progressziója észlelhető, mélypontján szervi elégtelenségre utaló jelekkel,

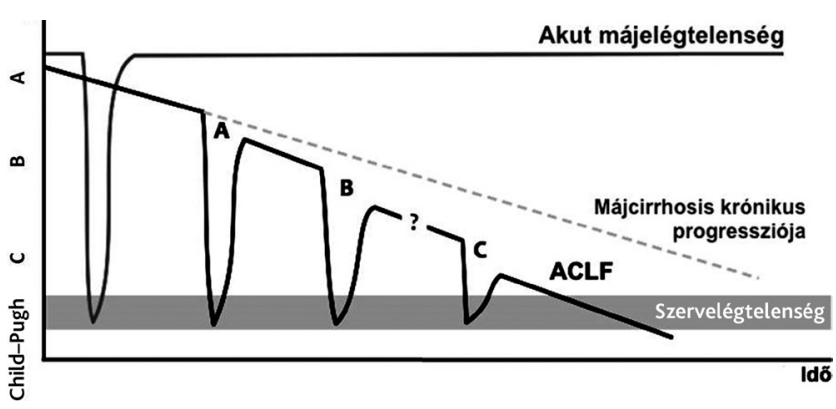

\begin{tabular}{l|l} 
1. ábra & $\begin{array}{l}\text { Az akut dekompenzáció jelentősége májzsugorban } \\
\mathrm{A}=\text { Child-Pugh A stádium; } \mathrm{B}=\text { Child-Pugh B stádium; C = } \\
\text { Child-Pugh C stádium; ACLF = acute on chronic liver failure. }\end{array}$
\end{tabular} amely az új nómenklatúra szerint az „acute on chronic liver failure" [1]. Hátterében leggyakrabban bakteriális infekció áll.

\section{Intestinalis bakteriális transzlokáció}

Az intestinalis bakteriális transzlokáció (BT) során a baktériumok vagy produktumaik (az utóbbi időben ezeket - függetlenül attól, hogy Gram-pozitív vagy -negatív baktériumokról van szó - összefoglalóan endotoxinoknak hívják) a béllumenből a nyirokszervekbe, majd a keringésbe jutnak. Megfelelő innate immunválasz eredményeként szisztémás gyulladásos választ nem váltanak ki, gyorsan eliminálódnak. Bizonyos betegségekben, így májzsugorban is, a transzlokáció mértéke kórossá válik. A kialakuló magas endotoxinszint fontos következménye a májzsugorra jellemző keringésátrendeződés: a splanchnicus vasodilatatio és a portalis hypertensio.

A BT kórossá válásának hátterében több tényező áll. A cirrhosis súlyosságától függően romlik a szervezet védekezőképessége, a leggyakoribb szerzett immunbiányos állapotról van szó, amely érinti az innate és az adaptív immunitást [2]. Fehérjehiány esetén csökken az opszoninok szintje [3]. A folyamatosan emelkedő mennyiségben jelenlevő endotoxinok kimerítik a polimorfonukleáris leukocyták (PMN) és a monocyták aktivitását $[4,5,6]$. Megfelelő immunfunkciók hiányában a transzlokálódott baktériumok és származékaik nem kerülnek kiszürésre a bél, illetve a máj immunsejtjei által. A párhuzamosan emelkedő portanyomás miatt a bél ödémássá válik, a mucosasejtek között lévő szoros kapcsolatok (tight junction) lazulnak, így sérül a mechanikus barrierfunkció [7]. Megváltozik a bélflóra [8], amelynek szintén van jelentősége, mivel a különböző baktériumok eltérő valószínűséggel transzlokálódnak [9]. A vékonybél bakteriális túlnövekedés (SIBO) gyakori jelenség májzsugorban, ami ugyancsak fokozza a baktériumok átjutását a bélfalon $[10,11]$.

Egészségesekben a transzlokálódó bakteriális antigének a mesenterialis nyirokcsomókig jutva csak lokális immunválaszt provokálnak. Cirrhosisban nagyobb mennyiségben átlépő baktériumok és endotoxinok a gyengült immunvédekezés miatt a keringésbe kerülnek. A máj Kupffer-sejtjeinek aktiválása, gyulladásos reakciója hozzájárul az akut dekompenzációhoz társuló parenchymás funkcióvesztéshez, míg a megemelkedő endotoxinszint a porta nyomásának növekedését provokálja. Emiatt a bakteriális transzlokációnak alapvető szerepe van a betegség lefolyásában és progressziójában.

\section{A spontán bakteriális peritonitis}

Az SBP egy olyan hasűri fertőzés, amely perforáció vagy más nyilvánvaló intraabdominalis fertőzőforrás nélkül alakul ki. Majdnem kizárólag ascitessel bíró cirrhosisos betegekben előforduló kórkép. Alap- és klinikai kutatások is arra utalnak, hogy leggyakrabban a fokozott intes- 
tinalis transzlokáció következtében a keringésbe jutó baktériumok hozzák létre, amelyek a rossz antibakteriális tulajdonságú ascitesben elszaporodnak $[12,13]$.

Az SBP a kórházi ellátást igénylő cirrhosisos betegek körében a leggyakoribb fertőző megbetegedés. Hospitalizált betegek 25-37\%-ában észlelt fertőzések 22-23\%-át jelenti $[14,15,16,17]$. Evans és munkatársainak tanulmányában tünetmentes járóbetegek körében az SBP prevalenciája 1,5-3,5\% volt [18]. Mortalitása magas. Az első SBP-s epizód kórházi halálozását 30\% és 50\% közöttinek találták [19], de az egyéves túlélés is rossz, 28,5\%os [20], ami azt jelenti, hogy az SBP megjelenése az életkilátásokat jelentősen rontja. Az infekció ismétlődése egy éven belül 35-69\%-ban várható [21].

Az ezredforduló körüli felmérések idején ascitesből az esetek mintegy kétharmadában a bélflórában normálisan előforduló Gram-negatív baktériumok (GNB) tenyésztek ki (körülbelül 50\%-ban E. coli), illetve a Gram-pozitív kórokozók (GPC) közül az enterococcusok, amelyek szintén a bélflóra tagjai. A bakteriális transzlokációból származó szóródás elméletét támogatta, hogy amennyiben egyéb úton (például portalis nyomást csökkentő kezelés révén) sikerül a $\mathrm{BT}$ mértékét csökkenteni, úgy az SBP incidenciája is csökken [22]. A bél antibiotikummal történt dekontaminációja szintén csökkenti az SBP kialakulásának valószínúségét [23]. Ezek alapján az SBP-t a BT tükrének tartották. Az utóbbi években azonban az ascitesből tenyészthető baktériumok spektruma változott, ami egyértelművé tette egyéb belépési kapuk létezését is (bármely bacteraemiával járó primer fertőzés: légúti, bőr-, húgyúti infekció vagy invazív beavatkozás - például endoszkópos vérzéscsillapítás - kapcsán kialakult nyálkahártya-sérülések). Ilyenkor a várható kórokozók elsősorban GPB-k, legtöbbször a Streptococcus speciesek. Arányuk az elmúlt néhány évben fokozatosan nő, egyes tanulmányokban már meghaladta a GNB-két [24, 25]. Nosocomialis infekciók esetén a GPB-k aránya $63 \%$ körül van [26]. A GPB-k irányába történő eltolódást legalább részben a nosocomialis és egészségügyi ellátáshoz kötötten megjelenő SBP-k gyakoribbá válása magyarázza.

\section{Az SBP hajlamositó tényezôi}

Nagyobb valószínűséggel számíthatunk SBP kialakulására, ha a májbetegség súlyos (SBP-ben szenvedő betegek 70\%-a Child-Pugh C stádiumba tartozik [27]), ha gastrointestinalis vérzés észlelhető, ha előzőleg a betegnek már volt SBP-je, ha az ascites fehérjetartalma alacsony $(<15 \mathrm{~g} / \mathrm{l})$, vagy a lipopoliszacharid-kötő protein (LBP) szérumkoncentrációja magas. Ez utóbbit a BT indirekt markerének tartják [28]. A fertőzés további rizikófaktorának tekinthető az alacsony szérumnátriumszint [27], amely valójában szintén súlyosabb májbetegséget jelez.

Cirrhosisosokban a sérült lokális celluláris és humorális immunmechanizmusok miatt romlik a baktériumok eltávolítása (clearance). Az antibakteriális hatás függ attól, hogy a PMN-sejtek milyen mértékben jutnak be a peritonealis térbe, valamint függ az aktivitásuktól, amit az opszonizáció mértéke befolyásol. A PMN-ek szerepét állatkísérletes modellben bizonyították [29]. Felmerült, hogy a kemotaxisukat szabályzó fehérjék polimorfizmusának szerepe lehet az SBP-re való fogékonyságban [30].

A súlyosabb májbetegség súlyosabb fehérjeszintéziszavart jelent, az ascites alacsony fehérjetartalma pedig szoros összefüggést mutat a hasüri folyadék csökkent opszonin (markere a C3-szérumszint) és antibakteriális aktivitásával [12]. Wiest és mtsai úgy találták, hogy ha az ascitesben található összfehérje $15 \mathrm{~g} / \mathrm{l}$-nél magasabb, az SBP incidenciája $1 \%$ alatt van, $15 \mathrm{~g} / 1$ alatti értéknél akár a 27-41\%-ot is elérheti [31]. Az SBP kialakulásának esélyét tovább növeli a reticuloendothelialis rendszer aktivitásának ismert csökkenése, illetve az immunrendszer genetikai polimorfizmusai (TLR2, NOD2) [32].

A gastrointestinalis vérzés elhúzódó bacteraemiával jár [33], ami magyarázza a vérzéseket követően jelentkező SBP-ket. A májbetegség súlyosságával párhuzamosan romlik az immunvédekezés, a fehérjeszintézis, illetve nő az ascites megjelenésének esélye is. A májelégtelenséget jelző paraméterek (bilirubin $>55 \mathrm{~mol} / \mathrm{L}$, thrombocytaszám<98 G/1) az SBP független rizikófaktorainak bizonyultak [31]. Retrospektív esetkontroll-vizsgálatok a protonpumpagátló (PPI-) kezelést hozták összefüggésbe az SBP kialakulásával $[34,35]$. Az erős savszekréció-gátlás a gyomorsav antibakteriális hatásának kikapcsolásával a szájon át bekerülő baktériumok túlélését, így a vékonybélbe jutását segítik, amely miatt nagyobb valószínűséggel alakul ki SIBO. A bakteriális túlnövekedés fokozza a BT-t.

\section{A spontán bakteriális peritonitis diagnózisa}

Az SBP felismerése sokszor nehéz. Az esetek nagy részében, elsősorban korai stádiumban, tünetmentes lehet. Jelentkezhetnek a peritonitis, a hashártyaizgalom helyi jelei, mint a hasi fájdalom, hányás, hasmenés, esetleg ileus. Hőemelkedés, láz, hidegrázás, hypothermia ritkán fordul elő. Gyakran csak a májfunkció nem megmagyarázható romlása, a hepaticus encephalopathia megjelenése vagy az ascites diuretikumrezisztenssé válása hívja fel rá a figyelmet. Súlyos szövődménye a hepatorenalis szindróma, illetve a szisztémás gyulladásos válasz részjelenségeként kialakuló sokszervi elégtelenség.

$\mathrm{Az}$ ascitesben mért PMN-szám (>250/ $\mathrm{mm}^{3}$ ) és/vagy a pozitív ascites tenyésztési lelet bizonyítja a diagnózist. Tekintettel arra, hogy a tenyésztési eredményre néhány napot várni kell, illetve jelentős az álnegatív esetek aránya, a kezelést a diagnosztikus paracentesis eredménye alapján el kell kezdeni, és szükség esetén az antibiogram megérkezését követóen módosítani kell. Tekintettel a tünetszegénységre, diagnosztikus paracentesis indokolt minden újonnan megjelenő ascites esetén. Célszerú ismert asciteses beteg esetén is elvégezni, kórházi felvételt indokló állapotban vagy ha a májfunkció hirtelen romlá- 
sát észleljük, tudatzavar vagy felső tápcsatornai vérzés jelentkezik, infekcióra utaló tüneteket észlelünk, illetve ha hepatorenalis szindróma alakul ki [36]. Haemorrhagiás ascites esetén, ahol az ascites vörösvérttest- (vvt.-) tartalma meghaladja a $10000 / \mathrm{mm}^{3}$-t, korrekcióra van szükség: minden 250 vvt. után a neutrofilszámot l-gyel csökkenteni kell. A régebbi guideline-ok a neutrofilek kézi számolását javasolták, mivel alacsony mennyiségnél az automaták pontatlanok voltak. A mai automaták használata során különbséget nem találtak a két módszer között, ami kényelmesebbé és gyorsabban elérhetővé teszi a diagnózist [37]. Mivel a neutrofilszám értékelése esetenként lassú lehet, felvetődött a tesztcsíkok használata, de ezek érzékenységét a vizsgálatok még nem tartják megfelelőnek, így nem ajánlottak [38]. Ágy melleti gyors diagnosztika céljából új próbálkozás az ascites calprotectin-szint meghatározása, amely Burri és mtsai szerint magas szenzitivitással és specificitással (100\%, illetve 90\%) jelzi az emelkedett PMN-számot az ascitesben [39]. Az infekció biztos igazolása és egyúttal az antibiotikum-érzékenység meghatározása tenyésztés útján lehetséges. A mintavétel helyesen az ágy mellett aerob és anaerob hemokultúrás palackba történő 10-10 ml ascites leoltásával történik. Még az így vett minták esetén is 20-50\%-ban álnegatív eredményt kapunk, ami azt jelenti, hogy a tenyésztés nem kellően szenzitív vizsgálat [12], mégis nélkülözhetetlenül fontos az antibiotikumérzékenyég feltérképezése céljából. A pozitív kultúra közösségben szerzett fertőzések esetén leggyakrabban a Gram-negatív E. coli-t, kórházi fertőzések alkalmával a GPB-k közül streptococcusokat és enterococcusokat igazol [40]. Azokat az eseteket, amikor az ascites PMNszáma meghaladja a $250 / \mathrm{mm}^{3}$-t, de a mintából nem tenyészik ki baktérium, kultúranegatív spontán bakteriális peritonitisnek nevezzük. Tünetei és kezelési módja megegyezik a kultúrapozitív SBP-vel. Pozitív tenyésztési eredmény $250 / \mathrm{mm}^{3}$ alatti PMN-számmal a bakter ascites, amely elképzelés szerint az SBP felé vezetó úton az első lépés, a baktériumok kolonizációját jelzi a gyulladásos válasz kialakulását megelőzően. Más esetekben a hasưri folyadék átmeneti, spontán reverzibilis kontaminációjáról van szó. Előfordul, hogy zajló szisztémás infekció kapcsán kerül észlelésre, ilyenkor az infekciót okozó patogén szóródásának tartható, a klinikai képet szisztémás gyulladásos tünetek dominálják [41].

A spontán bakteriális pleuralis empyema a mellüri folyadéknak az SBP-hez hasonló fertőzése, és az esetek 50\%-ában SBP-vel együtt jelentkezik. Ennek diagnózisa, thoracocentesis során vett minta analízisén alapszik, amely vagy pozitív tenyésztéses vizsgálati eredmény, vagy $250 / \mathrm{mm}^{3}$-nél magasabb PMN-szám alapján mondható ki. Negatív tenyésztési eredmény mellett $500 / \mathrm{mm}^{3}$-nél magasabb PMN szükséges a kórisme felállításához [42].

Fontos elkülöníteni a másodlagos bakteriális peritonitist az SBP-től, ahol a fertőzés oka bélperforáció vagy egy hasi szerv gyulladásos megbetegedése. Azokban az esetekben kell másodlagos peritonitisre gondolni, ami- kor a jelentkező lokális tünetek súlyosabbak, jelentősen emelkedett a PMN-szám és az ascitesből mért összefehérjeérték. Ilyenkor többféle kórokozó is kimutatható a mintából. Gondolni kell rá, ha a beteg nem reagál megfelelően a terápiára [41].

\section{A spontán bakteriális peritonitis kezelése}

A kezelést rögtön a diagnózis felállításakor el kell kezdeni empirikus antibiotikum-terápiával. Közösségben szerzett SBP esetén GNB-törzsek kóroki szerepére számíthatunk. Nosocomialis megbetegedés kapcsán általában GPB-k, illetve polirezisztens kórokozók igazolhatók. Ennek ellenére még nincs olyan nemzetközi ajánlás, ami ezt figyelembe venné az antibiotikum-rezsim kiválasztásakor. A nosocomialis SBP (N-SBP) terápiája során gyakrabban van szükség az empirikusan ajánlott antibiotikum cseréjére annak hatástalansága miatt, míg a közösségben szerzett SBP-nél (community acquired; CA-SBP) erre ritkábban kerül sor. Ezzel párhuzamosan a mortalitás is magasabb N-SBP esetén [43]. A jelenleg elfogadott guideline szerint empirikus kezelésként harmadik generációs cefalosporin alkalmazása szükséges legalább öt napon keresztül, azonban N-SBP esetén ezt a választást egyre inkább megkérdőjelezik. A kezelés hatékonyságának ellenőrzésére, annak kezdetétől számított 48 óra elteltével, újabb abdominalis paracentesist kell végezni. Amennyiben az ascites neutrofilszáma nem csökken legalább 25\%-kal, a terápia sikertelen, antibiotikum-váltás szükséges. Stabil állapotú betegek esetén vénásan kezdett, majd orális adagolással folytatott amoxicillin/ klavulánsav kezelés a cefotaximterápiához hasonló eredményeket hozott költséghatékonyabban [44]. Használható még ciprofloxacin iv. vagy második naptól orális alkalmazással (1. táblázat) [41]. Az empirikus antibiotikum-választáskor célszerü figyelembe venni a profilaktikus, illetve nemrégiben zajlott infekció kezelése céljából alkalmazott antibiotikum-terápiát. Az újonnan megjele-

1. táblázat |Az SBP empirikus kezelésének lehetőségei

\begin{tabular}{lll}
\hline Antibiotikum & & Napi dózis \\
\hline $\begin{array}{l}\text { Harmadik generációs } \\
\text { cefalosporinok }\end{array}$ & Cefotaxim & $3 \times 2 \mathrm{~g}$ \\
\cline { 2 - 3 } & Ceftriaxon & $1 \times 2 \mathrm{~g}$ \\
\cline { 2 - 3 } & Cefonicid & $2 \times 2 \mathrm{~g}$ \\
\hline Iv. amoxicillin + klavulánsav & & $3-4 \times 1,2 \mathrm{~g}$ \\
\hline Per os/iv. flurokinolonok & Ofloxacin & $2 \times 400 \mathrm{mg}$ \\
\cline { 2 - 3 } & Ciprofloxacin & $2 \times 500 \mathrm{mg}$ \\
\hline ESBL+: karbapenemek & Imipenem & $4 \times 0,5 \mathrm{~g}$ \\
\cline { 2 - 3 } & Meropenem & $3 \times 1 \mathrm{~g}$ \\
\hline
\end{tabular}

Iv. = intravénás 
nő infekció során ettől eltérő hatásmechanizmusú készítményt kell választani.

Amennyiben a kezelést fluorokinolonnal kezdtük, és ez nem volt hatékony, cefotaxim vagy ceftriaxon adása a következő lépés. Megelőzően fluorokinolonprofilaxisban részesült beteg esetén mindenképpen cefalosporinnal kell kezdeni. Ennek hatástalansága esetén Staphylococcus aureus, illetve Enterococcus-fertózés lehetősége miatt a terápiát amoxicillin/klavulánsavval $(3-4 \times 1,2 \mathrm{~g}$ iv.) vagy ampicillin/szulbaktámmal (3-4 × 1,5 g iv.) kell kiegészíteni. Amennyiben az ellátóhelyen az MRSA gyakori, úgy $2 \times 1 \mathrm{~g}$ vankomicinnel célszerü a kiegészítés. A vankomicin vesekárosító hatása miatt különös óvatosságot igényel.

Érdemes külön említést tenni az Enterococcus okozta fertőzésekről, mert ezek a baktériumok genetikusan rezisztensek a szokásos empirikus terápiaként alkalmazott cefalosporinokra. Az általuk okozott SBP mortalitása különösen magas. Májzsugorban nem szenvedő betegek Enterococcus-infekciója esetén ajánlott terápiájuk ß-laktám antibiotikum mellé adott aminoglikozid. Cirrhosis esetén az aminoglikozidok kerülését ajánlják, nephrotoxicitásuk miatt. Az Enterococcus-fertőzések magas mortalitása miatt azonban sokszor rákényszerülünk alkalmazására. A májelégtelenség súlyosságától és az SBP jelenlététől függetlenül is ezen antibiotikumok adása során magas arányban alakul ki veseelégtelenség [44]. Csak elkerülhetetlen esetben, a vesefunkció szoros követése és a beteg megfelelő hidrálása mellett szabad alkalmazni májcirrhosisos betegben aminoglikozid típusú antibiotikumot [45]! Vankomicinrezisztencia az Enterococcusokban alig fordul elő [46], ezért beépítése szükséges lehet, de a vankomicin vesekárosító hatásával is számolni kell.

A különösen veszélyeztetett betegekben (tartós kórházi kezelés, centrális vénás katéter, előző 30 napon belüli antibiotikum-terápia, súlyos májbetegség) az ESBLtermelő törzsek nagyobb valószínúséggel fordulnak elő, emiatt ezen betegek SBP-je esetén az ESBL-termelőkre is hatékony karbapenemeket javasolják kezdő antibiotikumként. A hatékony terápia késése jelentôsen növeli a mortalitást [47].

SBP kezelése során az antibiotikum akkor hagyható el, ha az ascites PMN-száma $\left(<250 / \mathrm{mm}^{3}\right)$ és a CRP normalizálódott [48].

Az SBP legveszélyesebb szövődménye az l-es típusú hepatorenalis szindróma. Mind a túlzott vízhajtó kezelés, mind az ismételt, nagy volumenú ascitespunkciók gyorsíthatják a progressziót. Minden olyan gyógyszer, amely nephrotoxicus, kerülendők az SBP teljes gyógyulásáig [49]. A megfelelő folyadékbevitel és óvatos diuretikus kezelés mellett az intravénás albumin adása javíthatja a kimenetelt. Bár egyértelmú konszenzus nincs, a szerzők többsége egyetért az első napon $1,5 \mathrm{~g} / \mathrm{ttkg}$, a harmadik napon $1 \mathrm{~g} / \mathrm{ttkg}$ humán albumin iv. adásának javaslatával, amely csökkenti a hepatorenalis szindróma incidenciáját (30-ról 10\%-ra) és javítja a rövid távú túlélést [50].

\section{Az SBP profilaxisa}

Tekintettel arra, hogy az SBP gyakran vezet a májzsugor akut dekompenzációjához, illetve a rövid és hosszú távú mortalitást jelentősen fokozza, célszerû a megelőzésére törekedni. Mivel SBP kialakulása előrehaladott májbetegekben leggyakrabban gastrointestinalis vérzést követően, alacsony ascitesfehérje-koncentráció esetén, illetve SBP lezajlását követően várható, ezekben az esetekben merül fel az antibiotikumok profilaktikus alkalmazása. Az SBP kialakulásának hátterében leggyakrabban BT áll, a megelózéséhez olyan antibiotikumot ajánlott választani, amely hatékony a bélbaktériumokkal szemben, de nem károsítja túlzottan a protektív anaerob mikrobákat. Erre a legalkalmasabbnak a norfloxacint tartják. Tartós vagy gyakori antibiotikum-kezelés a rezisztencia kialakulásának veszélyével jár, emiatt a megfelelő antibiotikumválasztás mellett fontos a legveszélyeztetettebb betegcsoport kiválasztása is. Másik alternatíva lehetne a fel nem szívódó antibiotikumok használata profilaxis céljából, amelynek káros szisztémás mellékhatásaival nem kell számolni. A rendelkezésre álló készítmények közül a rifaximin túnik a legalkalmasabbnak. Cirrhosisban elsősorban a hepaticus encephalopathia megelőzésére és mérséklésére ajánlják. Eddig nem észlelték rezisztencia kialakulását. Enyhe cirrhosis esetén hatékonyan csökkenti a cirrhosis szövődményeinek előfordulását az alacsony rizikójú betegekben, ugyanakkor a magas rizikójú betegek esetén nem ennyire meggyőzőek az eredmények, további kutatások szükségesek [45].

Májzsugorban gastrointestinalis vérzést, illetve endoszkópos beavatkozást követően jelentős mértékú bacteriaemiával kell számolni. Nemcsak az SBP, hanem az egyéb bakteriális infekciók is gyakoribbak. A fertőzések növelik a porta nyomását, emiatt a vérzés megállítása nehezebb, magasabb az újravérzés kockázata, ami miatt jelentôs mortalitásnövekedés várható. Az adatok azt mutatják, hogy előrehaladott cirrhosisos betegek gastrointestinalis vérzését és endoszkópos kezelését követően alkalmazott antibiotikum-profilaxis javítja a túlélést, csökkenti a szövődmények gyakoriságát (az SBP incidenciája $70 \%$-kal csökken) és rövidíti a kórházi tartózkodás hosszát [51, 52]. Legáltalánosabban a norfloxacint használják, amelyet $2 \times 400 \mathrm{mg}$ dózisban a vérzést követően hét napig kell alkalmazni. Amennyiben a májbetegség súlyos (ascites, encephalopathia, jelentős alultápláltság vagy $50 \mu \mathrm{mol} / \mathrm{l}$ feletti bilirubinérték), $\mathrm{l} \times 2 \mathrm{~g}$ dózisban alkalmazott ceftriaxont hatékonyabbnak találták [53].

$\mathrm{Az}$ alacsony fehérjekoncentráció az ascitesben a csökkent komplementaktivitás markere, amely az SBP-re való hajlam jelentős fokozódásával jár. Vizsgálatok szerint, amennyiben ez az eltérés előrehaladott májzsugorral társul, a betegek mindenképpen profitálnak napi $400 \mathrm{mg}$ norfloxacin adásából. Nemcsak az SBP előfordulása és a halálozás csökken, hanem ritkábban fordul elő a hepatorenalis szindróma is. Valószínúleg a BT csökkenése áll a háttérben [54]. Amennyiben a májbetegség enyhe, ez 
az összefüggés még nem világos. Ezért alacsony ascitesfvs.-szám esetén is csak azokban a betegekben ajánlható primer prevenció, akiknek elörehaladott májzsugoruk van.

Az SBP visszatérésének esélye egy éven belül körülbelül $70 \%$. Az egyéves túlélés rossz, 30-50\%, emiatt meg kell fontolni a májtranszplantációt. Fontos a következő epizód megelőzése, a szekunder prevenció, amelyre szintén a norfloxacint tartják alkalmasnak napi 400 mg dózisban. Alkalmazása valószínúleg a májtranszplantációig vagy a beteg haláláig indokolt, illetve, ha az ascites megszüntethető, a cirrhosis kompenzálódik, a profilaxis elhagyandó [4l].

A kinolon rendszeres alkalmazása, a vártnak megfelelően, fokozta a bélbaktériumok körében a kinolonrezisztencia előfordulását. Arra vonatkozóan, hogy a közelmúltban elterjedő rezisztens baktériumtörzsek hogyan befolyásolják a profilaxis eredményességét, eddig még nem történt vizsgálat. Az utóbbi időben azonban egyre több kinolonrezisztens baktériummal történt fertőzést írtak le, jelenlétük esetén kérdéses a profilaxis hatásossága. A rezisztencia miatt, bár az említett betegcsoport egyértelmúen profitál az antibiotikum-védelemből, populációs szinten, hosszú távon a kinolonok hatástalanná válásával kell számolni, ezért vannak, akik ellenzik az alkalmazását.

\section{A profilaxis alternatio lehetöségei}

A profilaxis másik lehetősége az SBP-t indukáló rizikófaktorok csökkentése. Protonpumpagátló (PPI) kezelés mellett gyakoribb a hasüri folyadék gyulladásának megjelenése, emiatt májzsugorban szenvedő betegnek csak megfelelő, szigorú indikáció alapján és lehetőleg csak átmenetileg szabad PPI-t adni [55].

Mivel a különböző bélbaktériumok nem egyforma mértékben transzlokálódnak, felmerült annak a lehetősége, hogy probiotikumok alkalmazásával befolyásolni lehetne a BT-t. Cirrhosisos betegekben tartós probiotikus kezelést követően igazolható volt a fekális flóra változása, a patogén baktériumok arányának csökkenése, a hepaticus encephalopathia akut és tartós javulása, az ammóniaszint csökkenése, valamint a máj állapotának javulása is. Több tanulmányban úgy találták, hogy enyhe encephalopathiás tünetek javíthatók probiotikumok alkalmazásával $[56,57]$. Ennek hátterében a BT csökkenését, az endotoxinszint mérséklődését és így szekunder hatásainak elmaradását valószínűsítették. Állatkísérletekben azonban nem sikerült bizonyítani a BT mérséklődését probiotikumkezelés esetén [58]. Jelenleg kevés klinikai tanulmány foglalkozik a probiotikumoknak az SBP kialakulására gyakorolt hatásával [59]. Egyelöre a rendelkezésre álló adatok nem támogatják kedvező hatásuknak elméletét.

A BT egyik fontos oki tényezője a portalis nyomás emelkedése. Az emelkedett portalis nyomás rontja a nyálkahártya tight junction funkcióját, ezáltal növeli a bél permeabilitását [60]. A nem szelektív béta-blokkolók (propranolol, nadolol) kedvező hatása a nyelőcsővarixvérzések primer és szekunder prevenciójában egyértelmü [61]. A nem szelektín béta-blokkolók alkalmazásakor nemcsak csökken a portalis nyomás, hanem gyorsul a béltranzit is, ezáltal csökken a bakteriális túlnövekedés lehetősége. Feltételezhetően a kemotaxis elősegítése, a gyulladásos citokinfelszabadulás támogatása és ezen keresztül némi antibakteriális hatás is hozzájárul hatásához [31]. Metaanalízis igazolta, hogy nem szelektív béta-blokkolók (propranolol) adása esetén ritkábban várható SBP kialakulása [60]. A bakteriális transzlokáció mérsékléséhez a HVPG 11\%-os csökkenése szükséges. Korábban elképzelhetőnek tartották, hogy a nem szelektív béta-blokkolók a fluorokinolonprofilaxis alternatívájává válnak az SBP primer és szekunder prevenciójában. Azonban dekompenzált májzsugor esetén a gyógyszer által létrehozott keringésváltozások rontották a betegek túlélését [62], így pont az SBP szempontjából legveszélyeztetettebb betegcsoportban nem használhatóak.

\section{Következtetés}

Az SBP a májzsugorban szenvedő betegek gyakori fertőzése, amely rontja a beteg életkilátásait. A fertőzés idején a máj akut dekompenzációját provokálhatja, hosszú távon a progressziót gyorsítva vezet a beteg halálához. Tünetei legtöbbször jellegtelenek. Időben történő felismeréséhez az ascites diagnosztikus próbapunkcióját el kell végezni minden olyan esetben, amikor a máj funkciójának nem magyarázható romlását észleljük. Ezt régen az alapbetegség akut romlásának tartottuk, ma azonban tudjuk, hogy az akut dekompenzáció hátterében majdnem mindig fel nem ismert infekció áll, az esetek többségében SBP. Sikeres kezelése a máj állapotának látványos javulásával jár.

Anyagi támogatás: A közlemény megírása, illetve a kapcsolódó kutatás anyagi támogatásban nem részesült.

Szerzôi munkamegosztás: V. B.: Az irodalmi adatok áttekintése, rendszerezése, a szöveg megírása. V. Zs.: A téma kiválasztása, a review felépítésének, szerkezetének meghatározása, a szöveg megírása. V. E.: Az infektológiai szempontok ellenőrzése, korrekciója.

Érdekeltségek: A szerzőknek nincsenek érdekeltségeik.

\section{Irodalom}

[1] Moreau, R., Jalan, R., Gines, P., et al.: Acute-on-chronic liver failure is a distinct syndrome that develops in patients with acute decompensation of cirrhosis. Gastroenterology, 2013, 144(7), 1426-1437.

[2] Christou, L., Pappas, G., Falagas, M. E.: Bacterial infection-related morbidity and mortality in cirrhosis. Am. J. Gastroenterol., $2007,102(7), 1510-1517$. 
[3] Homann, C., Varming, K., Hogåsen, K. et al.: Acquired C3 deficiency in patients with alcoholic cirrhosis predisposes to infection and increased mortality. Gut, 1997, 40(4), 544-549.

[4] Leber, B., Mayrhauser, U., Rybczynski, M., et al.: Innate immune dysfunction in acute and chronic liver disease. Wien. Klin. Wochenschr., 2009, 121(23-24), 732-744.

[5] Fiuza, C., Salcedo, M., Clemente, G., et al.: In vivo neutrophil dysfunction in cirrhotic patients with advanced liver disease. J. Infect. Dis., 2000, 182(2), 526-533.

[6] Gomez, F., Ruiz, P., Schreiber, A. D.: Impaired function of macrophage $\mathrm{F}_{\mathrm{c}} \gamma$ receptors and bacterial infection in alcoholic cirrhosis. N. Engl. J. Med., 1994, 331(17), 1122-1128.

[7] Wiest, R., Garcia-Tsao, G.: Bacterial translocation (BT) in cirrhosis. Hepatology, 2005, 4l(3), 422-433.

[8] Bajaj, J. S., Hylemon, P. B., Ridlon, J. M., et al.: Colonic mucosal microbiome differs from stool microbiome in cirrhosis and hepatic encephalopathy and is linked to cognition and inflammation. Am. J. Physiol. Gastrointest. Liver Physiol., 2012, 303(6), G675-G685.

[9] Gómez-Hurtado, I., Santacruz, A., Peiró, G., et al.: Gut microbiota dysbiosis is associated with inflammation and bacterial translocation and in mice with $\mathrm{CCI}_{4}$-induced fibrosis. PLoS ONE, 2011, 6(7), e23037.

[10] Corazza, G. R., Menozzi, M. G., Strocchi, A., et al.: The diagnosis of small bowel bacterial overgrowth. Reliability of jejunal culture and inadequacy of breath hydrogen testing. Gastroenterology, 1990, 98(2), 302-309.

[11] Chang, C. S., Yang, S. S., Kao, C. H., et al.: Small intestinal bacterial overgrowth versus antimicrobial capacity in patients with spontaneous bacterial peritonitis. Scand. J. Gastroenterol., 2001, 36(1), 92-96.

[12] Alaniz, C., Regal, R. E.: Spontaneous bacterial peritonitis: a review of treatment options. PT, 2009, 3(4), 204-210.

[13] Teltschik, Z., Wiest, R., Beisner, J., et al.: Intestinal bacterial translocation in rats with cirrhosis is related to compromised Paneth cell antimicrobial host defense. Hepatology, 2012, 55(4), 11541163

[14] Caly, W. R., Strauss, E.: A prospective study of bacterial infections in patients with cirrhosis. J. Hepatol., 1993, 18(3), 353358.

[15] Borzio, M., Salerno, F., Piantoni, L., et al.: Bacterial infection in patients with advanced cirrhosis: a multicentre prospective study. Dig. Liver Dis., 2001, 33(1), 41-48.

[16] Bajaj, J. S., O'Leary, J. G., Reddy, K. R., et al.: Survival in infection-related acute-on-chronic liver failure is defined by extrahepatic organ failures. Hepatology, 2014, 60(1), 250-256.

[17] Fernández, J., Acevedo, J., Castro, M., et al.: Prevalence and risk factors of infections by multiresistant bacteria in cirrhosis: a prospective study. Hepatology, 2012, 55(5), 1551-1561.

[18] Evans, L. T., Kim, W. R., Poterucha, J. J., et al.: Spontaneous bacterial peritonitis in asymptomatic outpatients with cirrhotic ascites. Hepatology, 2003, 37(4), 897-901.

[19] Thuluvath, P. J., Morss, S., Thompson, R.: Spontaneous bacterial peritonitis - in-hospital mortality, predictors of survival, and health care costs from 1988 to 1998. Am. J. Gastroenterol., 2001, 96(4), 1232-1236.

[20] França, A. V., De Souza, J. B., Silva, C. M., et al.: Long-term prognosis of cirrhosis after spontaneous bacterial peritonitis treated with ceftriaxone. J. Clin. Gastroenterol., 2001, 33(4), 295-298.

[21] Guarner, C., Solà, R., Soriano, G., et al.: Risk of a first community-acquired spontaneous bacterial peritonitis in cirrhotics with low ascitic fluid protein levels. Gastroenterology, 1999, 117(2), 414-419.

[22] Gonzalez-Suarez, B., Guarner, C., Villanueva, C., et al.: Pharmacologic treatment of portal hypertension in the prevention of community-acquired spontaneous bacterial peritonitis. Eur. J. Gastroenterol. Hepatol., 2006, 18(1), 49-55.
[23] Saab, S., Hernandez, J. C., Chi, A. C., et al.: Oral antibiotic prophylaxis reduces spontaneous bacterial peritonitis occurrence and improves short-term survival in cirrhosis: a meta-analysis. Am. J. Gastroenterol., 2009, 104(4), 993-1001.

[24] Friedrich, K., Nüssle, S., Reblen, T., et al.: Microbiology and resistence in first episodes of spontaneous bacterial peritonitis: implications for management and prognosis. J. Gastroenterol. Hepatol., 2016, 31(6), 1191-1195

[25] Piroth, L., Pechinot, A., Di Martino, V., et al.: Evolving epidemiology and antimicrobial resistance in spontaneous bacterial peritonitis: a two-year observational study. BMC Infect. Dis., 2014, $14,287$.

[26] Piano, S., Fasolato, S., Salinas, F., et al.: The empirical antibiotic treatment of nosocomial spontaneous bacterial peritonitis: Results of a randomized, controlled clinical trial. Hepatology, 2016, 63(4), 1299-1309.

[27] Schwabl, P., Bucsics, T., Soucek, K., et al.: Risk factors for development of spontaneous bacterial peritonitis and subsequent mortality in cirrhotic patients with ascites. Liver Int., 2015, 35(9), 2121-2128.

[28] Cesaro, C., Tiso, A., Del Prete, A., et al.: Gut microbiota and probiotics in chronic liver diseases. Dig. Liver Dis., 2011, 43(6), $431-438$

[29] Joyce, L. D., Hau, T., Hoffman, R., et al.: Evaluation of the mechanism of zymosan-induced resistance to experimental peritonitis. Surgery, 1978, 83(6), 717-725.

[30] Gäbele, E., Müblbaner, M., Paulo, H., et al.: Analysis of monocyte chemotactic protein-l gene polymorphism in patients with spontaneous bacterial peritonitis. World J. Gastroenterol., 2009, 15(44), 5558-5562.

[31] Wiest, R., Krag, A., Gerbes, A.: Spontaneous bacterial peritonitis: recent guidelines and beyond. Gut, 2012, 61(2), 297-310.

[32] Sipeki N., Antal-Szalmas, P., Lakatos P. L., et al.: Immune dysfunction in cirrhosis. World J. Gastroenterol., 2014, 20(10), 2564-2577.

[33] Blaise, M., Pateron, D., Trinchet, J. C., et al.: Systemic antibiotic therapy prevents bacterial infection in cirrhotic patients with gastrointestinal hemorrhage. Hepatology, 1994, 20(1), 34-38.

[34] Trikudanathan, G., Israel, J., Cappa, J., et al.: Association between proton pump inhibitors and spontaneous bacterial peritonitis in cirrhotic patients - a systematic review and meta-analysis. Int. J. Clin. Pract., 2011, 65(6), 674-678.

[35] Bajaj, J. S., Zadvornova, Y., Heuman, D. M., et al.: Association of proton pump inhibitor therapy with spontaneous bacterial peritonitis in cirrhotic patients with ascites. Am. J Gastroenterol., 2009, 104(5), 1130-1134.

[36] Rimola, A., Garcia-Tsao, G., Navasa, M., et al.:, the International Ascites Club: Diagnosis, treatment and prophylaxis of spontaneous bacterial peritonitis: a consensus document. J. Hepatol., 2000, 32(1), 142-153.

[37] Riggio, O., Angeloni, S., Parente, A., et al.: Accuracy of the automated cell counters for management of spontaneous bacterial peritonitis. World J. Gastroenterol., 2008, 14(37), 5689-5694.

[38] Nguyen-Khac, E., Cadranel, J. F., Thevenot, T., et al.: Review article: the utility of reagent strips in the diagnosis of infected ascites in cirrhotic patients. Aliment. Pharmacol. Ther., 2008, $28(3), 282-288$.

[39] Burri, E., Schulte, F., Muser, J., et al.: Measurement of calprotectin in ascitic fluid to identify elevated polymorphonuclear cell count. World J. Gastroenterol., 2013, 19(13), 2028-2036.

[40] Fernández, J., Navasa, M., Gómez, J., et al.: Bacterial infections in cirrhosis: epidemiological changes with invasive procedures and norfloxacin prophylaxis. Hepatology, 2002, 35(1), 140-148.

[41] European Association for the Study of the Liver: EASL clinical practice guidelines on the management of ascites, spontaneous bacterial peritonitis, and hepatorenal syndrome in cirrhosis. J. Hepatol., 2010, 53(3), 397-417. 
[42] Xiol, X., Castellvi, J. M., Guardiola, J., et al.: Spontaneous bacterial empyema in cirrhotic patients: a prospective study. Hepatology, 1996, 23(4), 719-723.

[43] Chon, Y. E., Kim, S. U., Lee, C. K., et al.: Community-acquired vs. nosocomial spontaneous bacterial peritonitis in patients with liver cirrhosis. Hepatogastroenterology, 2014, 61(136), 22832290.

[44] Garcia-Tsao, G., Wiest R.: Gut microflora in the pathogenesis of the complications of cirrhosis. Best Pract. Res. Clin. Gastroenterol., 2004, 18(2), 353-372.

[45] Lutz, P., Nischalke, H. D., Strassburg, C. P., et al.: Spontaneous bacterial peritonitis: The clinical challenge of a leaky gut and a cirrhotic liver. World J. Hepatol., 2015, 7(3), 304-314.

[46] Lee, J. H., Yoon, J. H., Kim, B. H., et al.: Enterococcus: not an innocent bystander in cirrhotic patients with spontaneous bacterial peritonitis. Eur. J. Clin. Microbiol. Infect. Dis., 2009, 28(1), 21-26.

[47] Song, K. H., Jeon, J. H., Park, W. B., et al.: Clinical outcomes of spontaneous bacterial peritonitis due to extended-spectrum beta-lactamase-producing Escherichia coli and Klebsiella species: a retrospective matched case-control study. BMC Infect. Dis., $2009,9,41$.

[48] Runyon, B. A.: Introduction to the revised American Association for the Study of Liver Diseases Practice Guideline management of adult patients with ascites due to cirrhosis 2012. AASLD Practice Guideline. Hepatology, 2013, 57(4), 1651-1653.

[49] Wong, F., Bernardi, M., Balk, R., et al., on behalf of the International Ascites Club: Sepsis in cirrhosis: report on the 7th meeting of the International Ascites Club. Gut, 2005, 54(5), 718-725.

[50] Koulaouzidis, A., Bhat, S., Saeed, A. A.: Spontaneous bacterial peritonitis. World J. Gastroenterol., 2009, 15(9), 1042-1049.

[51] Chavez-Tapia, N. C., Barrientos-Gutierrez, T., Tellez-Avila, F. I., et al.: Antibiotic prophylaxis for cirrhotic patients with upper gastrointestinal bleeding. Cochrane Database Syst. Rev., 2010, (9), CD002907.

[52] Kuo, M. T., Yang, S. C., Lu, L. S., et al.: Predicting risk factors for rebleeding, infections, mortality following peptic ulcer bleeding in patients with cirrhosis and the impact of antibiotics prophylaxis at different clinical stages of the disease. BMC Gastroenterol., 2015, 15, 61 .

[53] Fernández, J., Ruiz del Arbol, L., Gómez, C., et al.: Norfloxacin vs. ceftriaxone in the prophylaxis of infections in patients with advanced cirrhosis and hemorrhage. Gastroenterology, 2006, 131(4), 1049-1056.

[54] Fernández, J., Navasa, M., Planas, R., et al.: Primary prophylaxis of spontaneous bacterial peritonitis delays hepatorenal syndrome and improves survival in cirrhosis. Gastroenterology, 2007, 133(3), 818-824.

[55] Deshpande, A., Pasupuleti, V., Thota, P., et al.: Acid-suppressive therapy is associated with spontaneous bacterial peritonitis in cirrhotic patients: a meta-analysis. J. Gastroenterol. Hepatol., $2013,28(2), 235-242$.

[56] Liu, Q., Duan, Z. P., Ha, D. K., et al.: Synbiotic modulation of gut flora: effect on minimal hepatic encephalopathy in patients with cirrhosis. Hepatology, 2004, 39(5), 1441-1449.

[57] Bajaj, J. S., Saeian, K., Christensen, K. M., et al.: Probiotic yogurt for the treatment of minimal hepatic encephalopathy. Am. J. Gastroenterol., 2008, 103(7), 1707-1715.

[58] Wiest, R., Chen, F., Cadelina, G., et al.: Effect of Lactobacillusfermented diets on bacterial translocation and intestinal flora in experimental prehepatic portal hypertension. Dig. Dis. Sci., 2003, 48(6), 1136-1141.

[59] Pande, C., Kumar, A., Sarin, S. K.: Addition of probiotics to norfloxacin does not improve efficacy in the prevention of spontaneous bacterial peritonitis: a double-blind placebo-controlled randomized-controlled trial. Eur. J. Gastroenterol. Hepatol., $2012,24(7), 831-839$.

[60] Senzolo, M., Cholongitas, E., Burra, P., et al.: Beta-blockers protect against spontaneous bacterial peritonitis in cirrhotic patients: a meta-analysis. Liver Int., 2009, 29(8), 1189-1193.

[61] Feu, F., García-Pagán, J. C., Bosch, J., et al.: Relation between portal pressure response to pharmacotherapy and risk of recurrent variceal haemorrhage in patients with cirrhosis. Lancet, 1995, 346(8982), 1056-1059

[62] Sersté, T., Francoz, C., Durand, F., et al.: Beta-blockers cause paracentesis-induced circulatory dysfunction in patients with cirrhosis and refractory ascites: a cross-over study. J. Hepatol., $2011,55(4), 794-799$.

(Vitális Zsuzsanna dr., Debrecen, Nagyerdei krt. 98., 4032 e-mail: drvitaliszs@gmail.com)

Az Orvosi Hetilap 2016, 157, 1976. oldalán (49. szám) megjelent OH-Kvízre két helyes megfejtés érkezett.

A beküldők: Dr. Bíró László (Budapest) és Dr. Somogyi Erzsébet (Miskolc).

A nyerteseknek szívből gratulálunk.

Nyereményüket - egy, az Akadémiai Kiadó webáruházában

kedvezményes vásárlásra jogosító kupont - e-mailen küldjük el. 